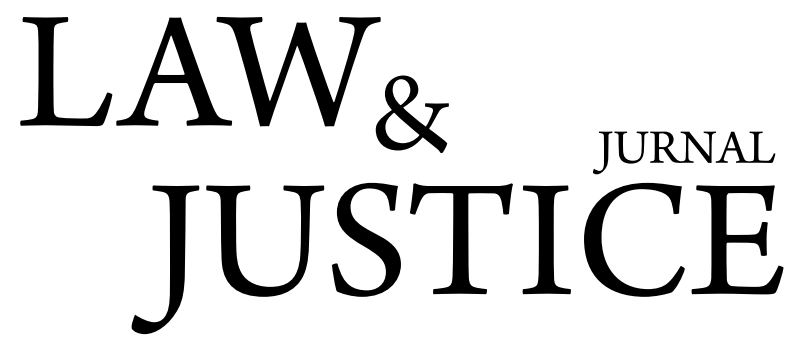

Volume 3, Nomor 1, April 2018

\title{
EFEKTIVITAS KEBIJAKAN PEMERINTAH DAERAH TERHADAP PENGEMBANGAN INDUSTRI KECIL DI KOTA JAYAPURA
}

\author{
Sebedeus Hitokdana \\ Magister Ilmu Hukum Universitas Sebelas Maret Surakarta \\ Jalan Ir Sutami No 36-A Kentingan Surakarta. Kode Pos, 57126 \\ Email: hits_sitok@yahoo.co.id
}

\begin{abstract}
Abstrak
Industri kecil sangat potensial untuk dikembangkan karena menyangkut upaya perluasan kesempatan kerja, peningkatan Produk Domestik Regional Bruto (PDRB), juga pemberdayaan masyarakat lokal. Pengembangan industri kecil di Kota Jayapura sebagai bagian dari industri kecil di Indonesia secara keseluruhan, membutuhkan perhatian yang sungguh dan kebijkan yang arif. Kebijakan itu harus mampu mendorong industri kecil di Kota Jayapura untuk dapat berkembang hingga menjadi mandiri. Oleh karena itu sangat menarik untuk mengetahui efektivitas kebijakan pengembangan industri kecil di Kota Jayapura, sehingga mampu mengidentifikasi faktor-faktor yang dapat mempengaruhi efektivitas kebijakan pengembangan industri kecil di Kota Jayapura. Secara teoritis efektivitas kebijakan pengembangan industri kecil di Kota Jayapura dijelaskan sebagai tindakan yang dilakukan baik oleh pemerintah, swasta maupun masyarakat yang mengakibatkan peningkatan pada bidang produksi dan pengolahan, pemasaran dan pengembangan sumber daya manusia serta pengembangan industri kecil melalui pelatihan, pendampingan dan hubungan kemitraan antara industri kecil dengan industri besar dan menengah di Kota Jayapura.
\end{abstract}

Kata kunci: efektivitas, kebijakan pemerintah, industri kecil.

\section{Pendahuluan}

Kebijakan industrialiasasi memiliki signifikan yang erat dengan strategi suatu negara dalam upaya percepatan pertumbuhan ekonomi makro, terutama bagi negara berkembang. Strategi industriallisasi telah diyakini oleh banyak negara di dunia, bahwa hanya dengan pengembangan industrialisasi, terutama yang berorientasi eksport, sebuah negara bisa memacu pertumbuhan ekonominya. Indonesia merupakan negara yang memiliki jumlah penduduk yang banyak dan wilayah yang cukup luas serta kekayaan alam yang cukup potensial untuk pengembangan industri bila dibandingkan dengan negara lain baik di kawasan Asia Tenggara maupun Asia Timur, namun pertumbuhan sektor industri di Indonesia jauh tertinggal dengan negara-negara seperti Korea Selatan, Taiwan, Hongkong, Singapura dan Malaysia.

Perubahan global yang terjadi dimana hendak diberlakukannya pasar bebas secara internasional pada tahun 2020 yang akan datang ikut mengharuskan dikembangkannya industri di Indonesia, terutama 
pembangunan dan pengembangan industri kecil yang berorientasi pada pasar dan ekspor. Untuk mengangkat kelompok masyarakat itu dari ketertinggalan dan juga sebagai upaya dalam mengentaskan kemiskinan, maka menurut Alim Muhammad dalam Dewanta dkk (1999) industri kecil/kerajinan mempunyai beberapa potensi untuk dikembangkan. Potensi tersebut harus dikembangkan secara terus menerus, karena di tengah penurunan kontribusi sektor pertanian terhadap produk nasional bruto (Hartanto Sigit dalam Suryana dkk, 1995), akibat semakin sempitnya lahan pertanian dan keterbatasan elastisitas tenaga kerja, sektor industri kecil dapat menjadi alternatif yang memadai (Alim Muhammad dalam Dewanta dkk, 1995).

Beberapa sebab mengapa industri kecil/kerajinan lebih menguntungkan untuk dikembangkan, antara lain (Alim Muhammad dalam Dewanta dkk, 1999) karena persyaratan dan keterampilan yang diperlukan tidak terlalu sulit, kebutuhan investasinya terjangkau oleh kebanyakan masyarakat, serta bahan baku produksi mudah diperoleh. Selain itu sektor ini juga memiliki elastisitas penyerapan tenaga kerja yang relatif lebih tinggi, bisa dilakukan secara komplementer dengan kegiatan produktif lainnya, memungkinkan mobilitas potensi sumber daya setempat, serta dapat menciptakan struktur ekonomi yang lebih terdeversifikasi sambil sekaligus mengurangi ketergantungan terhadap sektor pertanian.

Upaya pengembangan industri kecil di Indonesia sebenarnya sudah lama dilakukan oleh pemerintah, dimana pemerintah telah menetapkan dan memberlakukan beberapa kebijakan dalam upaya pengembangan industri kecil, diantaranya; Kredit Investasi Kecil, Kredit Usaha kecil, Kredit Modal Kerja Permanen. Undang-Undang Nomor 3 Tahun 2014 tentang Perindustrian, Undang-Undang Nomor 17 Tahun 2012 tentang Perkoperasian dan Undang-Undang Nomor 20 Tahun 2008 tentang Usaha Mikro, Kecil dan Menengah, yang peraturan pelaksananya diatur lebih lanjut dalam Peraturan Pemerintah Nomor 32 Tahun 1998 tentang Pembinaan dan Pengembangan Usaha Kecil.

Dengan adanya beberapa kebijakan pemerintah tersebut menunjukkan bahwa pemerintah sebenarnya sudah lama menaruh perhatian yang sungguh dan serius terhadap pengembangan industri kecil. Terlebih pada masa reformasi sekarang ini, dimana pemerintah lebih menitik beratkan pembangunan ekonomi pada ekonomi kerakyatan sebagai upaya pemberdayaan masyarakat untuk ikut terlibat aktif dalam pembangunan bangsa, baik pembangunan pada tingkat lokal atau daerah maupun pembangunan pada tingkat nasional. Namun dalam kenyataan perkembangan industri kecil di Indonesia sangat memprihatinkan. Hal itu terjadi karena lebih banyak perhatian dan energi yang dicurahkan oleh pemerintah kepada pembangunan ekonomi perkotaan daripada ekonomi pedesaan atau terhadap pembangunan dan pertumbuhan industri-industri besar dari pada industri kecil. Sebagai akibatnya perekonomian nasional dikuasai secara sepihak oleh pelaku ekonomi besar tertentu tanpa mempedulikan industri kecil yang ada dan potensial untuk mendukung industri besar itu sendiri, sehingga dengan sendirinya memastikan pertumbuhan dan perkembangan usaha kecil yang diterapkan nantinya menjadi basis perekonomian nsional di Indonesia ini.

Keadaan seperti diatas yang cenderung masih terus berlangsung sampai sekarang tidak mengurangi kemauan pemerintah untuk terus mengembangkan industri kecil di Indonesia. Dan begitu pentingnya pengembangan industri kecil ini, sehingga mendorong baik pemerintah, swasta maupun Lembaga Swadaya Masyarakat (LSM) untuk ikut terlibat secara aktif dalam berbagai program pembinaan dan pengembangan industri kecil di seluruh tanah air. Pola pembinaan dan pengembangan dengan menjalin hubungan kerjasama (kemitraan) antara usaha menengah dan besar dengan usaha kecil telah banyak dilakukan, bantuan modal dan peralatan (prasarana) pun sudah banyak diberikan, pendampingan industri kecil juga sudah dilaksanakan, namun disadari pula bahwa tingkat pertumbuhan dan peningkatan usaha kecil untuk menjadi usaha yang tangguh dan mandiri masih sangat terbatas atau masih sangat kecil, bahkan kehidupan usaha kecil cenderung pasang surut.

Untuk itu pembangunan dan pengembangan industri kecil harus lebih serius dan lebih baik, dalam arti upaya pengembangannya harus lebih profesional serta merata bagi seluruh industri kecil di Indonesia. Untuk pengembangan yang lebih baik, lebih efektif dan efisien serta yang lebih profesional, maka harus dilakukan secara berfokus pada masing-masing daerah. Karena pengembangan industri kecil secara nasional pasti sangat tidak efektif dan akan mengalami banyak kegagalan. Hanya dengn pengembangan industri kecil yang berfokus sesuai kebutuhan pada masing-masing daerah yang memungkinkan industri 
kecil untuk lebih bertumbuh dan berkembang dengan baik.

Kota Jayapura memiliki sebanyak 210 unit industri kecil untuk dikembangkan lebih lanjut yang terdiri dari industri hasil hutan dan perkayuan sebanyak 64 unit, industri tekstil 30 unit, industri percetakan 17 unit, industri logam mesin dan perekayasaan 19 unit, industri alat angkut 36 unit, industri elektronika dan aneka 23 unit, industri makanan 21 unit. (Kandepperindag). Industri kecil tersebut mengembangkan untuk menjadi salah satu sumber pendapatan bagi pembangunan Kota Jayapura, dan sebagai upaya penyediaan kesempatan kerja yang lebih luas bagi peningkatan angkatan kerja yang terus bertambah, sebagai akibat dari pertambahan mengalami banyak kegagalan. Hanya dengan pengembangan industri kecil yang berfokus sesuai kebutuhan pada masing-masing daerah yang akan memungkinkan industri kecil untuk lebih bertumbuh dan berkembang dengan baik dan berhasil, maka pengembangan industri secara nasional dengan sendirinya dapat berhasil pula, yang sudah tentu memperkuat perekonomian nasional.

Pengembangan industri kecil secara lokal pada masing-masing daerah di Indonesia membutuhkan kesiapan daerah, terutama faktor-faktor pendukungnya dan layak tidaknya suatu industri kecil tertentu untuk dikembangkan di suatu daerah tertentu, sesuai kebutuhan, peluang dan potensi yang tersedia pada daerah tersebut. Industri kecil tersebut dikembangkan untuk menjadi salah satu sumber pendapatan bagi pembangunan Kota Jayapura, dan sebagai upaya penyediaan kesempatan kerja yang lebih luas bagi peningkatan angkatan kerja yang terus bertambah, sebagai akibat dari pertambahan jumlah penduduk yang terus meningkat dari tahun ke tahun di Kota Jayapura.

Potensi pengembangan industri kecil di Kota Jayapura, meliputi: jumlah penduduk Kota Jayapura yang terus meningkat, yang memungkinkan tersedianya pasar yang lebih luas dan tenaga kerja dengan kualifikasi tertentu yang masih dapat diperoleh dari tenaga kerja tersebut. Sumber daya alam yang cukup tersedia, baik di Kota Jayapura maupun di Kabupaten Jayapura yang dapat memungkinkan pegembangan industri kecil tertentu terutama industri hasil hutan dan perkayuan serta beberapa industri kecil lainnya. Kota Jayapura merupakan Ibu Kota Provinsi Papua yang ikut memungkinkan tersedianya infrastruktur yang memadai untuk memudahkan dan mendukung kelancaran aktivitas dari industri kecil.

Sedangkan dari pemerintah, walaupun belum ada peraturan daerah yang mengatur secara khusus pengembangan industri kecil, namun ada komitmen bahwa (Laporan Pelaksanaan Tugas Pokok dan Fungsi Kandepperindag, 2000) pemberdayaan terhadap dunia usaha secara konsisten harus diakses oleh pemerintah melalui program pembinaan dan pengembangan unit-unit usaha yang telah eksis, peningkatan kemampuan sumber daya manusia industri kecil, mutu produk komoditi andalan, peningkatan kemampuan kewirausahaan sehingga diharapkan terjadi laju pertumbuhan ekonomi yang serasi dan seiring dengan peningkatan kualitas sumber daya manusia, pemerataan kesempatan berusaha dan kesempatan kerja serta peningkatan kesejahteraan masyarakat pada umumnya.

Walaupun demikian diakui bahwa pengembangan industri kecil di Kota Jayapura masih kurang menggembirakan dalam pengertian bahwa pertumbuhannya sering tidak stabil atau sering mengalami pasang surut. Agar dapat terciptanya suatu bentuk pengembangan yang lebih baik untuk mendukung perkembangan dan pertumbuhan industri kecil di Kota Jayapura yang tentunya dapat memperkuat ekonomi daerah Kota Jayapura, maka perlu adanya suatu penelitian dan kajian yang lebih mendalam tentang "Efektivitas Kebijakan Pemerintah Daerah Terhadap Pengembangan Industri Kecil Di Kota Jayapura".

\section{Rumusan Masalah}

Sejauh mana efektivitas kebijakan pemerintah terhadap pengembangan industri kecil di Kota Jayapura? 


\section{Kebijakan Pengembangan Industri Kecil di Kota Jayapura}

Pengembangan industri kecil telah dilakukan dengan suatu kebijakan oleh pemerintah yang merupakan intervensi pemerintah secara langsung terhadap pengembangan industri kecil tersebut, dengan harapan bahwa industri kecil dapat berkembang seperti yang diharapkan. Oleh karenanya keadaan tersebut terus mengundang perhatian dari pemerintah untuk menetapkan berbagai kebijakan yang diharapkan dapat menjamin pengembangan industri kecil untuk menjadi lebih baik lagi.

Pengembangan industri kecil di Kota Jayapura didasarkan pada beberapa kebijakan yang meliputi; kebijakan pengembangan ekonomi daerah, peningkatan peran daerah sebagai motivator, fasilitator dan mediator; penataan sistem penyaluran perizinan di bidang industri, perdagangan dan penanaman modal terpadu; pemberdayaan ekonomi rakyat yang meliputi KUB, Kopermas dan Perorangan/ informal; pembinaan dunia usaha melalui penciptaan iklan usaha yang kondusif untuk penanaman modal; memperkuat potensi/daya yang dimiliki masyarakat melalui peningkatan keterampilan tekhnis dan keterampilan usaha, permodalan dan akses pasar; serta mencegah terjadinya persaingan tidak sehat melalui sosialisasi Undang-Undang Nomor 5 Tahun 1999 tentang larangan Monopoli dan Persaingan tidak Sehat.

Dengan dasar kebijakan tersebut ada beberapa program kerja yang dilaksanakan sebagai upaya pengembangan industri kecil di Kota Jayapura yaitu; program pembinaan usaha kecil dan menengah pada sektor industri dan perdagangan yang dalam hal ini hanya dilihat sektor industri saja; program peningkatan utilitas kapasitas produksi; program pembinaan, pengembangan mutu produk; program pengembangan komoditi andalan; dan program pengembangan pengusaha kecil dan menengah.

Sejumlah kebijakan dan program kerja diatas menjadi dasar untuk mengembangkan industri kecil yang tentunya berada di lingkungan wilayah Kota Jayapura dengan sungguh-sungguh. Pengembangan industri kecil di Kota Jayapura melalui kebijakan tersebut terutama pada bidang-bidang yang dapat diuraikan lebih lanjut pada bagian-bagian berikut.

a. Pengembangan Produksi dan Pengolahan

Untuk mengembangkan bidang produksi dan pengolahan pada industri kecil di Kota Jayapura, maka berdasarkan kebijakan tersebut pemerintah Kota Jayapura melalui Dinas Perindustrian dan Perdagangan Kota Jayapura telah melaksanakan beberapa program pengembangan industri kecil yang diharapkan dapat merangsang dan menunjang proses pengembangan bidang produksi dan pengolahan untuk berkembang dengan baik. Program pengembangan bidang produksi dan pengolahan tersebut. (Dinperindag Jayapura 2000).

1) Program Peningkatan Utilitas Kapasitas Produksi, yaitu Peningkatan Sentra Binaan Industri Kecil dengan jenis kegiatan berupa : Bantuan revitalisasi sentra-sentra produksi.

2) Pembinaan dan Pengembangan Mutu Produk, dengan jenis kegiatan yang meliputi: (a) pengambilan sampel dan pengujian mutu komoditi industri lokal di Laboratorium Waena; (b) penyuluhan peningkatan mutu produk olahan (tepung sagu, minyak lawang, minyak kelapa, kripik pisang, bawang goreng, tenun motif Papua, ukiran tradisional dll.

3) Penyuluhan tekhnis produksi dan pengenalan teknologi melalui RRI;

4) Peningkatan informasi produksi melalui penyuluhan dan penyebarluasan informasi produk dan kapasitas produksi industri kecil dan menengah.

Program kerja ini bila dicermati, maka sangat memadai dan memungkinkan industri kecil di Kota Jayapura untuk memperoleh pembinaan dan pengembangan yang maksimal dalam upaya meningkatkan kemampuan produksi dan pengolahan dari masing-masing industri kecil tersebut.

b. Pengembangan Pemasaran

Untuk menunjang keberadaan dan keberlangsungan industri kecil di Kota Jayapura, maka pemasaran merupakan salah satu fungsi yang sangat diharapkan perannya. Oleh karena itu, untuk merangsang kegiatan pemasaran dari industri kecil di Kota Jayapura untuk berjalan 
normal, maka ada beberapa program pemasaran yang diharapkan dapat merangsang kelancaran kegiatan pemasaran hasil-hasil produksi industri kecil tersebut.

c. Pengembangan Sumber Daya Manusia

Sesuai amanat kebijakan pengembangan industri kecil, bahwa pengembangan sumber daya manusia pada industri kecil sangat mutlak untuk dilaksanakan. Pengembangan sumber daya manusia tersebut wajib dilakukan baik oleh pemerintah, swasta maupun masyarakat. Penegembangan sumber daya manusia dari pemilik/pemimpin dan tenaga kerja pada industri kecil di Kota Jayapura telah dilaksanakan melalui beberapa program pelatihan yang meliputi:

1) Pelatihan manajemen usaha

2) Pelatihan kewirausahaan

3) Pelatihan keterampilan tehnis.

Program pelatihan ini dilaksanakan baik oleh pihak pemerintah dalam hal ini yang diwakili oleh Dinas Perindustrian dan Perdagangan Kota Jayapura maupun instansi lain yang terkait, secara khusus melalui kerjasama dengan Fakultas Ekonomi Universitas Cenderawasih Jayapura. Pelatihan yang diberikan masih terbatas kepada sebagian kecil industri kecil yang ada di Kota Jayapura terutama kelompok industri kecil yang dibina oleh pihak pemerintah melalui Dinas Perindustrian dan Perdagangan Kota Jayapura.

\section{Ukuran Efektivitas Kebijakan Pengembangan Industri Kecil di Kota Jayapura}

Efektivitas kebijakan pengembangan industri kecil di Kota Jayapura dapat diukur melalui sejauh mana kebijakan tersebut mengakibatkan peningkatan yang positif pada industri kecil di Kota Jayapura. Peningkatan itu bisa dapat dilihat melalui program pengembangan industri kecil pada bidang produksi dan pengolahan, pemasaran dan sumber daya manusia, sehingga industri kecil di Kota Jayapura dapat bertumbuh terus menjadi industri kecil yang tangguh dan mandiri.

Disini dilihat sejauh mana kebijakan pengembangan industri kecil yang telah dilaksanakan oleh pemerintah Kota Jayapura melalui Dinas Perindustrian dan Perdagangan Kota Jayapura dapat merangsang bidang-bidang pengembangan industri kecil untuk mengalami peningkatan. Dengan ini jelas kebijakan pengembangan produksi dan pengolahan telah memungkinkan peningkatan pada jenis produk dari industri kecil di Kota Jayapura. Tetapi peningkatan itu belum menggambarkan suatu kondisi yang baik karena belum mencapai separuh dari keseluruhan industri kecil yang ada di Kota Jayapura.

Selain jenis produk industri kecil yang diharapkan mengalami peningkatan dengan adanya kebijakan pengembangan produksi dan pengolahan pada industri kecil, tetapi peningkatan lain yang diharapkan juga dari pengembangan bidang produksi dan pengolahan ini adalah pada hasil produksi dari industri kecil tersebut. Dengan demikian untuk hasil produksi dari industri kecil telah mengalami peningkatan yang positif.

Secara keseluruhan untuk bidang produksi dan pengolahan dari industri kecil di Kota Jayapura telah mengalami peningkatan yang positif dengan adanya peningkatan pengembangan bidang produksi dan pengolahan pada industri kecil di Kota Jayapura. Peningkatan pada jenis produk dari industri kecil, walaupun positif tetapi masih belum mencapai separuh dari keseluruhan industri kecil di Kota Jayapura. Sedangkan peningkatan pada hasil produksi dari industri kecil lebih memperkuat penambahan hasil produksi yang terjadi sebelum adanya peningkatan pengembangan pada bidang produksi dan pengolahan industri kecil.

\section{Simpulan}

Kebijakan pengembangan industri kecil tersebut secara keseluruhan telah memungkinkan peningkatan pada bidang-bidang pengembangan industri. Kebijakan pengembangan produksi dan pengolahan serta kebijakan pengembangan pemasaran telah memungkinkan peningkatan yang benar pada masing-masing bidang yaitu bidang produksi dan pengolahan serta bidang pemasaran dari industri kecil di Kota Jayapura. Kecuali kebijakan pengembangan sumber daya manusia pada industri kecil yang 
belum memungkinkan peningkatan yang besar dan merata bagi setiap industri kecil di Kota Jayapura.

Untuk faktor-faktor yang mempengaruhi kebijakan pengembangan industri kecil, terdapat dua faktor yang memberikan pengaruh positif untuk peningkatan bidang-bidang pengembangan industri kecil yaitu nilai-nilai kebijakan pengembangan industri kecil dan jiwa wirausaha, sedangkan visi pengembangan industri kecil belum dapat memberikan pengaruh yang positif untuk peningkatan bidangbidang pengembangan industri kecil.

\section{Daftar Pustaka}

Dewanta, Awan Setia, dkk, 1999, Kemiskinan dan Kesenjangan di Indonesia, ctk 2, Aditya Media, Yogyakarta.

Dunn, William N., 1999, Pengantar Analisa Kebijakan Publik, ctk. 2, Gadjah Mada University Press, Yogyakarta.

Jones, Charles O., 1991, Pengantar Kebijakan Publik, Ed. I, ctk.1 CV. Rajawali, Jakarta.

Steers, Richard M., 1997, Organization Effectiviness, A Behavioral View, Goodyear Publishing Company, Inc., Santa Monica, California.

Suryana, Ahmad Syamsuddin, dkk, 1995, Mulai dengan Usaha Kecil Merintis Karir Kewirausahaan Anda, ctk.1, Penerbit Pusat Pengembangan Usaha Kecil Kawasan Timur Indonesia (PUKTI) Ujung Pandang kerjasama dengan Konrad Adenauer Stifting Internasionales Institut.

Tambunan, Tulus, 1999, Reformasi Industrialisasi Perdesaan, ctk. 1, Media Ekonomi Publishing (MEP) Universitas Trisakti, Jakarta.

------------, Perkembangan Industri Kecil di Indonesia, PT. Mutiara Sumber Widya, Jakarta.

Tohar M., 1999, Membuka Usaha Kecil, Kanisius, Yogyakarta.

Wahab, Solichin Abdul, 1997, Analisis Kebijaksanaan : dari formulasi ke implementasi kebijaksanaan negara, Ed.I ctk.2, Bumi Aksara, Jakarta.

Wahab, Solichin Abdul, 1990, Pengantar Kebijaksanaan Analisis Kebijaksanaan Negara, ctk.1, Rineka Cipta, Jakarta.

Undang-Undang Republik Indonesia Nomor 3 Tahun 2014 tentang Perindustrian

Undang-Undang Republik Indonesia Nomor 17 Tahun 2012 tentang Perkoperasian

Undang-Undang Republik Indonesia Nomor 20 Tahun 2008 tentang Usaha Mikro Kecil dan Menengah

Peraturan Pemerintah Republik Indonesia Nomor 32 Tahun 1998 tentang Pembinaan dan Pengembangan Usaha Kecil

, 1999, Laporan Akhir Kegiatan Pendampingan dan Pembianaan, Pengembangan Pengusaha Kecil di Kabupaten Dati II Jayapura, Jayawijaya dan Merauke (revisi) : Kerjasama Biro Bina Perekonomian Pemda Tingkat I Papua dengan STIE Ottow dan Geissler Jayapura.

--------, 1999, Laporan Lanjutan Pendampingan Pendampingan dan Pembinaan Pengusaha Kecil Asli Papua di Kabupaten Dati II Jayapura, Merauke dan Jayawijaya oleh Lembaga Penelitian Universitas Cenderawasih Jayapura.

---, 2000, Laporan Pelaksanaan Tugas Pokok dan Fungsi Kantor Departemen Perindustrian dan Perdagangan Kota Jayapura, Tahun 1999/2000.

---------, 2000, Papua Dalam Angka 1999: Kerjasama BAPPEDA Provinsi Papua dengan Biro Pusat Statistik Provinsi Papua.

--------, 2000, Kota Jayapura Dalam Angka Tahun 1999: Kerjasama BAPPEDA Kota Jayapura dengan Badan Pusat Statistik Kota Jayapura. 